Illinois State University

ISU ReD: Research and eData

Faculty and Staff Publications - Milner Library

Milner Library

2015

\title{
Utilizing a Time-to-Shelf Study to Start a Conversation on Change
}

Sally Gibson

Illinois State University, sgibson@ilstu.edu

Follow this and additional works at: https://ir.library.illinoisstate.edu/fpml

Part of the Library and Information Science Commons

\section{Recommended Citation}

Gibson, Sally, "Utilizing a Time-to-Shelf Study to Start a Conversation on Change" (2015). Faculty and Staff Publications - Milner Library. 66.

https://ir.library.illinoisstate.edu/fpml/66

This Article is brought to you for free and open access by the Milner Library at ISU ReD: Research and eData. It has been accepted for inclusion in Faculty and Staff Publications - Milner Library by an authorized administrator of ISU ReD: Research and eData. For more information, please contact ISUReD@ilstu.edu. 
Utilizing a time-to-shelf study to start a conversation on change

Abstract:

Purpose: This paper shows the value of benchmarking organizational performance in order to enable conversations about workflow analysis and potential changes.

Design/methodology/approach: Data from a time-to-shelf study is compared to literature describing similar studies at other academic libraries which enable the decision making process for a new workflow.

Findings: The results of a time-to-shelf study necessitated a change in workflow. This paper examines how the data enabled staff to agree to changes and supported the decision making process.

Originality/value: This paper examines the impact of evidence-based decision making on the performance and workflow of a technical services department.

\section{Summary}

Over the course of nine months in the 2013-2014 academic year, the Cataloging, Acquisitions, and Processing (CAP) Department at Illinois State University conducted a time-to-shelf study. The original purpose was to gather benchmark data and determine the length of time needed for a book to reach the shelves. The findings uncovered the need to evaluate workflows in order to improve the department's performance. A review of the literature and the data from the time-to-shelf study enabled the department head to start a conversation about workflow changes with the subject selectors and the CAP staff.

Changes to any process-related workflow are often met with reluctance by those who are involved in them. Centering the conversation on facts and the best practices of other libraries enabled the conversation to focus on performance and the need to meet expectations. The study focused on workflow procedure rather than individual performance. Desired outcomes defined the changes to workflow. 


\section{Introduction}

Technical Services departments balance the competing demands of core responsibilities and special projects. Accomplishing all the tasks in a timely manner can be challenging especially with limited staff. The Cataloging, Acquisitions, and Processing (CAP) Department at Illinois State University's Milner Library is comprised of three units working together as a team. Eight employees are affiliated with the Acquisitions unit, nine employees with the Cataloging unit, and one employee with the Processing unit. The Department Head oversees all three units. From 2009 to 2013, responsibilities of staff who have since retired were often absorbed into other positions as opposed to hiring new employees to replace the retirees. Balancing the anticipation of future staffing needs, modifying current workflows, and letting go of legacy practices is difficult, at best, and is compounded by the need for work to continue.

Over the course of nine months in the 2013-2014 academic year the CAP Department conducted a timeto-shelf study. The purpose of the study was to gather benchmark data and determine the length of time needed for material to reach the shelves. An additional goal was to examine the workflow to determine any inefficiencies delaying the progress of a title through the process. An item was tracked from the time it arrived in the Acquisitions unit to the time it was placed in the general circulating stacks. Rush and reserve items were not included in the study since those materials receive first priority and do not spend time in the new book review room or on the book trucks waiting to be cataloged or processed.

Time-to-shelf studies have the basic principle of tracking an item from the time of receipt to the time placed on the shelves. A title is received, cataloged with an OCLC record when one is available, holdings and item level information are added to the library's online catalog, and a barcode and call number label are placed on the material. CAP Department staff maintained a normal workflow during the study. Staff members were asked not to give special attention to the flagged materials. Material was to be processed in the order in which it was received. The purpose of the study was to capture a realistic representation of the workflow. Anomalies in the data would indicate areas of concern and help facilitate workflow changes. Individual performance was not critiqued. The department performance was examined as a whole and by each unit.

Methodology

The Milner Library time-to-shelf study is based on studies conducted at other university libraries. For two weeks in October and April a half page paper flag was placed in every item which arrived in the library during the designated timeframe. Periodicals, gifts, and microform were not included in the study. The flag tracked how long the item remains at each step in the workflow. Upon arrival in the department the flag was stamped with the date received ("date in"). As the title moved through the process the flag would be date stamped to determine how long the title was in acquisitions, cataloging, processing, and on the distribution shelves. Flagged items did not receive special treatment, following the first in/first out practice. At the time of arrival, the type of order was indicated by placing the date stamp under approval plan title, firm order title, or standing order title. Firm orders were further divided by material type such as book, DVD, kit, music recording, music score, or object. If the title was sent to the bindery or needed preservation treatment within the process, that information was also indicated on the flag with a date in and date out for conservation.

The Time-to-Shelf flag was modeled on the one used in the Schroeder and Howland (2011, p. 132) study. The data captured included acquisitions date in and date out, cataloging date in and date out, and processing date in and date out. Schroeder and Howland also tracked the time in and time out in addition to the date(s), but this was not deemed necessary for the purpose of our study. A general understanding of the number of days was sufficient. The study conducted at East Carolina University's Joyner Library suggested numbering the flags as an accurate means of tracking the material (Dragon \& Barricella 2006, 
p. 14). This suggestion was incorporated into the flags used for the study at Milner Library. A mock up flag was provided to everyone in the department for feedback. A trial run was conducted for one week in September, with the intention of an opportunity to work through any questions about the flag and the study process. Slight modifications were made to the flag based on the feedback of the trial.

Modifications included adding 2013-2014 at the top of the flag to indicate the timeframe of the study and adding continuations as a material type. Continuations also known as standing orders have a slightly different workflow since they are not placed in the new book review room. By including continuations as a material type the workflow for all material types except periodicals would be captured. The study was conducted October 7-18, 2013 and April 14-25, 2014.

Results

The overall results from the study indicated that order type and material type require different timelines. Music recordings and DVDs required the least amount of time at 17 days and 19 days respectively. Firm order books required 27 days and approval plan books required 43 days. Music scores required 58 days since they are always sent to the bindery which added an average of 35 days. The difference of 16 days between firm order books and approval plan books warranted an investigation into the current workflow. At the time of the study, approval plan titles spent three weeks in the book review room. Selectors review the titles and determine if they should be added to the collection. The timeline difference between firm order titles and approval plan titles could be explained by the time in the book review room, but it was necessary to determine if that was the only cause of the discrepancy indicated on the flags. The department also examined the difference between the fall study and the spring study.

In October 2013, the department received 404 items, and in April 2014, 722 items were received. March had the highest number of received items at 778. Thus March and April combined had the largest number of orders received during the fiscal year. This influx of orders increased the time-to-shelf process for books to 33 days or 6 weeks in the spring compared to 22 days or 5 weeks in the fall. The increase in orders is directly related to the annual March $15^{\text {th }}$ order deadline. Selectors are required to spend $50 \%$ of their funds before the start of the spring academic semester and the rest of the funds by March $15^{\text {th }}$, in accordance with state/university policy regarding deadlines for encumbered fiscal year funds. The largest number of orders occurred in the month of March with 1,259. January was the second highest with 865 . Between January and April the number of orders received was $49 \%$ of the total for the fiscal year. This workflow pattern causes bottlenecks in the process, since the orders are not received on a consistent basis. The difference in the time-to-shelf between the fall study and the spring study for the firm order titles was not a surprise, given that this is an annual occurrence.

The bigger difference occurred with the approval plan titles. Approval plan titles arrive weekly, so a large influx of orders does not occur as it does with the firm orders. The number of titles varies between 50 and 120 since it is based on a profile match. Approval Plan titles required an average of 43 business days or 9 weeks to complete the receipt to shelf process. The overall average time in the book review room was 17 days and 21 days in cataloging. During October, the average time was 19 days in the book review room and 11 days in cataloging. In April the average time was 17 days in the book review room and 28 days in cataloging. Further investigation into the approval plan titles revealed that carts were not moved into cataloging on a weekly basis. Selectors were given additional time in January and February. In fact during the month of January and February, carts were in the book review room as long as 6 weeks. This delay creates a backlog of titles, since carts arrive into the cataloging unit in groups rather than on a weekly basis.

Comparison to other studies 
A review of the literature found several reasons for moving to shelf-ready materials. In an overview of outsourcing for Technical Services, Sweetland (2001, p. 173) states cost savings and improved workflow as the main arguments in favor of shelf-ready services. Quality issues are main reasons for those against it. As might be expected, cataloging staff are conscientious and proud of their work, making the debate about outsourcing problematic by the very nature of the discussion topic. A 2013 U.S. academic libraries survey by Tomlin and Kandarasheva proves the quality issues are more fear than fact. The survey results in the assessment of shelf-ready materials management practices reported a cataloging and processing error rate between 0 to 3 percent. The quality objection is often raised prior to implementation and proven to be unfounded (Tomlin \& Kandarasheva 2014, pp. 160-161). Discussions at Milner Library follow a similar thought pattern. The library has multiple floor locations, complicating the cataloging process, since the location is determined by the call number rather than a generic stack location. Staff concerns include loss of meaningful work, and the perception that the in-house process is just as expeditious as that of a cataloging vendor.

The data from the Milner Library time-to-shelf study indicates that the in-house process is not equal to the vendor provided services. Several factors contribute to the length of time for a book to reach the shelves. Orders are received on a daily basis, but the amount of material varies. A large influx of materials creates a bottleneck effect and increases the time that items (or trucks of materials) spend waiting for attention due to volume. In addition to their core areas of responsibilities, staff attend meetings, take time off, and participate in short term projects outside their day-to-day duties. Other library departments often generate projects for the CAP Department with varying completion times. The projects do not always occur at times that are convenient for the CAP department, and usually become additional work without additional or temporary increases in staffing for the unexpected project. Thus, one hundred percent of any given day by any given staff member is not spent on the core areas of responsibility. It is unrealistic to set quotas and insist that the staff work at a faster pace. The pace of work is not the issue, rather, the combination of additional projects, meetings, and variety in the amount of materials prevent a consistent and steady outflow of materials.

Shelf-ready materials can reduce turnaround time. Tomlin and Kandarasheva (2014, p. 158) surveyed U.S. academic libraries about their shelf-ready materials management and cataloging practices. 85.2 percent of the respondents implemented shelf-ready services in order to reduce material turnaround time. 70.4 percent wanted to reassign staff to emerging areas of need. Thus, efficiency was the primary reason for the adoption of shelf-ready services. Previous published studies found similar results. The University of Florida determined that a shelf-ready workflow reduced the time-to-shelf and reduced staff processing time (Crump \& Carrico 2001, p. 109). Brigham Young University discovered that shelf-ready books were placed on shelves 33 days earlier than those that were non-shelf-ready. (Schroeder \& Howland 2011, p. 131) Libraries who adopted some shelf-ready procedures/workflows were also able to reallocate technical services staff to other areas of need, with the overall result proving that "shelf-ready" placed the materials on the shelves faster and with fewer staff.

\section{Workflow considerations}

It is important to examine the workflow of other libraries and determine what efficiencies could be utilized at Milner Library. The workflow in a Technical Services department has an established routine and process. Workflow efficiencies can easily be incorporated. The best practices of other libraries are also transferrable. A key consideration is whether efficiencies could be gained by cataloging in-house or by outsourcing it. Bibliographic records for current imprints are readily available and rarely require local modifications. Allowing staff to focus on unique local collections and materials would be a better utilization of their time, with most firm order titles converted to shelf-ready items. 
Prior to the time-to-shelf study, the perception of the CAP department was that the length of time it took for materials to be placed on the shelves was reasonable. The department felt that the backlog of materials was nonexistent. There was concern from outside the department, but without concrete data it was difficult to determine if the external perceptions were realistic. The time-to-shelf study enabled a discussion about desired turnaround time that was based on data as opposed to feelings or impressions. A general lack of awareness of the time required for each step in the acquisitions, cataloging, and processing workflow also created challenges in terms of determining if the expectations were reasonable. The study was able to raise awareness for each step in the process and questioned whether current workflow practices contributed to the identified problems and concerns.

An analysis of published time-to-shelf studies indicates that it is possible to place material on the shelf faster by sub-contracting out for vendor services. Libraries that did not have shelf-ready material were consistent with the timeline encountered by Milner Library (Hurlbert \& Dujmic 2004, p. 5). Minor workflow changes are certainly possible, but the largest decline in number of days from receipt to shelf is a result of shelf-ready material. The decision to continue supporting a timeline of seven weeks is called into question when another library accomplishes the same task in seven days by using the shelf-ready process.

\section{Workflow changes}

An honest conversation with the subject selectors about their expectations revealed an interest in having the material readily available to our students. At the July 2013 Collection Development meeting the results of the time-to-shelf study were presented. Nine of the fourteen subject selectors were in attendance. After the presentation of the results, the CAP Department Head inquired if nine weeks for the approval plan titles was acceptable. One of the subject selectors stated that nine weeks and even six weeks was not acceptable. Given that a semester is sixteen weeks, it would be unfortunate for new material to be unavailable for nearly half of the semester. A discussion ensued about required outcomes and possible solutions including information about current practices at other university libraries. There was a general verbal agreement that 43 days required for approval plan titles were considered unacceptable. Reasonable expectations were set and changes came from both sides of the workflow. The timeline was set for three weeks from receipt to shelf. The selectors' interest in reviewing the material prior to cataloging contributed to the delay in making the materials readily available. It was a matter of balancing the desire to see the physical book and the desire to place the book in the hands of our students. Determining the library's priorities and referring to the strategic map ensured that the decision was based upon the common understanding of the goals and purpose of Milner Library.

Approval plan titles are current imprints. Selectors felt that it was vital to have the titles in the hands of the students as quickly as possible. Conversations with acquisitions librarians at other institutions and the approval plan vendor revealed that most university libraries allow for a one week review of approval plan titles. After a presentation of informative facts and discussion regarding the length of time in the book review room, the bottleneck phenomenon, and an examination of the results from the time-to-shelf study, the selectors agreed to a workflow change. Approval Plan titles went from three weeks of availability to one week in the book review room.

In addition to the one week change in the book review room for approval plan titles, the CAP Department is taking a fresh look at shelf-ready services. With the data from the time-to-shelf study, a comparison can now be made in terms of in-house versus vendor services. In the past, evaluation was based on instinct or feelings and the perception that the in-house would yield the same end result as the vendor services. The data now will show which method will place the titles on the shelves faster, and if there will be a cost in terms of the quality of the bibliographic records. The discussion will be based on facts rather than anecdotal information. 


\section{Conclusion}

In the past, discussions on workflow and timelines at Milner Library were driven by past practice, feelings and anecdotal information. By focusing on data it was possible to determine if the expectations and needs of students and other library departments could be met with the current workflow in place. Individuals were not singled out and changes were made that benefitted the department as a whole. Based on the results of the time-to-shelf study and a comparison to the studies at other libraries, it was determined that minor changes to the workflow could be made to improve the time to shelf duration, however the greatest impact would come from adopting shelf-ready services. Data from the study enabled the conversation to focus on expectations and determine the best method for placing the material into the hands of Illinois State University students faster. By examining the data as a whole, it prevented a focus on individual performance and decisions based on perceptions.

\section{References}

Crump, M. \& Carrico, S. 2001, "It's Academic", Library Resources \& Technical Services, vol. 45, no. 2, pp. 104109.

Dragon, P. \& Barricella, L.S. 2006, "Assessment of Technical Services Workflow in an Academic Library: A Timeand-Path Study", Technical Services Quarterly, vol. 23, no. 4, pp. 1-16.

Hurlbert, T. \& Dujmic, L.L. 2004, "Factors Affecting Cataloging Time: An In-House Survey", Technical Services Quarterly, vol. 22, no. 2, pp. 1-14.

Schroeder, R. \& Howland, J.L. 2011, "Shelf-ready: A cost-benefit analysis", Library Collections, Acquisitions, \& Technical Services, vol. 35, no. 4, pp. 129-134.

Sweetland, J.H. 2001, "Outsourcing library technical services - what we think we know, and don't know", Bottom Line: Managing Library Finances, vol. 14, no. 3, pp. 164-176.

Tomlin, N. \& Kandarasheva, I. 2014, "Ready or Not?", Library Resources \& Technical Services, vol. 58, no. 3, pp. 153-168. 